\title{
A MICROMACHINED CHEMICAL SENSOR FOR SEA FLOOR ENVIRONMENTS: INITIAL RESULTS \\ Tao Li ${ }^{l^{*}}$, Kang Ding ${ }^{2}$, William E. Seyfried, $\mathrm{Jr}^{2}{ }^{2}$, and Yogesh B. Gianchandani ${ }^{1}$ \\ ${ }^{1}$ Center for Wireless Integrated MicroSensing and Systems (WIMS ${ }^{2}$ ), University of Michigan, Ann Arbor, MI \\ ${ }^{2}$ Department of Geology and Geophysics, University of Minnesota, Minneapolis, MN
}

\section{ABSTRACT}

This paper reports a micromachined chemical sensor intended for harsh environments such as those near hydrothermal vents at the sea floor. The sensor is intended to measure the $\mathrm{pH}$, dissolved $\mathrm{H}_{2}$ and $\mathrm{H}_{2} \mathrm{~S}$, and temperature. The device is $12 \mathrm{~mm}$ in diameter and $6 \mathrm{~mm}$ in effective length, including packaging. A $\mathrm{YSZ}|\mathrm{HgO}| \mathrm{Hg}$ solid electrode is used as a common electrode for measurement of the three chemical quantities. The YSZ diaphragm used for this electrode is $<500 \mu \mathrm{m}$ thick, allowing sufficient ion conductance at temperatures $>35^{\circ} \mathrm{C}$. The other electrodes are thin-film metal electrodes fabricated on the same YSZ diaphragm: an $\mathrm{Ag} \mid \mathrm{AgCl}$ reference electrode for $\mathrm{pH}$ sensing, an $\mathrm{Ag} \mid \mathrm{Ag}_{2} \mathrm{~S}$ electrode for $\mathrm{H}_{2} \mathrm{~S}$ sensing, and a Pt electrode for $\mathrm{H}_{2}$ sensing. The two temperature sensors are thin film Pt resistors. Initial tests have been performed to test the functionality of the $\mathrm{pH}$ and $\mathrm{H}_{2} \mathrm{~S}$ sensors; measurements are in line with expectations.

\section{INTRODUCTION}

In situ chemical sensing in harsh geological environments is important for many applications. One example is the exploration of hydrothermal vents located at mid-ocean ridges. On the adjacent sea floor, these vents not only create rich mineral deposits that drive mining interests, but also nurture more than 1300 previously-unknown biological species that do not depend on the sun [1]. Knowledge of chemical components and quantities, especially $\mathrm{pH}$ and redox (e.g. dissolved $\mathrm{H}_{2}$ and $\mathrm{H}_{2} \mathrm{~S}$ ), can provide invaluable insight into such biological communities and lead to better understanding of the bio-geochemical environments at these locations [2-3]. Rapid and direct in situ measurement of these quantities is essential to obtain accurate and meaningful readings. However, these measurements also present significant challenges due to high temperature and high pressure that are typical in these and other geochemical environments.

Chemical sensors designed to meet the needs in these extreme geochemical conditions are few [2-5]. A sensor based on yttriastabilized-zirconia (YSZ) ion-conductive ceramic was reported for sensing of $\mathrm{pH}$, dissolved $\mathrm{H}_{2}$ and dissolved $\mathrm{H}_{2} \mathrm{~S}$, and deployed at deep-sea hydrothermal vents at temperatures up to $400^{\circ} \mathrm{C}$ and pressure levels up to $40 \mathrm{MPa}$ [2-3]. This conventional sensor had $2.5 \mathrm{~cm}$ diameter and $>30 \mathrm{~cm}$ length. Reduced sensor size is desirable to allow more precise measurement of high-gradient conditions. It can also enable spatial distribution of sensor clusters to allow simultaneous characterization at multiple sites in a biological community near the vents.

This paper reports the design and initial results of a micromachined chemical sensor based on a thin YSZ diaphragm for measurement of $\mathrm{pH}$, dissolved $\mathrm{H}_{2}$, dissolved $\mathrm{H}_{2} \mathrm{~S}$ and temperature (Fig. 1). The sensor design is intended to provide compatibility with environments that have high pressure $(>10$ $\mathrm{MPa})$ and relatively high temperature $\left(\leq 150^{\circ} \mathrm{C}\right)$, such as that in a typical biological community near the vents (Fig. 2). The sensor has $12 \mathrm{~mm}$ diameter and $\approx 6 \mathrm{~mm}$ effective length with packaging. The design details are described, along with the fabrication process. Preliminary tests of the sensor have been performed in regular laboratory settings to verify the validity of the design and the functionalities of the sensor. The measurement results are reported.

\section{DEVICE CONCEPT}

The micromachined sensor is intended to sense $\mathrm{pH}$, dissolved $\mathrm{H}_{2}$, dissolved $\mathrm{H}_{2} \mathrm{~S}$, and temperature. To measure the three chemical quantities, three electrochemical cells are included (Table I). The $\mathrm{YSZ}|\mathrm{HgO}| \mathrm{Hg}$ solid electrode is a common electrode used in all three electrochemical cells. It is used for $\mathrm{pH}$ sensing with a $\mathrm{Ag} \mid \mathrm{AgCl}$ reference electrode. The ion conductance of the YSZ ceramic in the electrode allows measurement of the activity of $\mathrm{H}^{+}$ ions in fluid with presence of other chemical components [6]. This electrode is also used as a reference electrode to eliminate the effect of $\mathrm{pH}$ on output voltage potentials, both in the measurement of dissolved $\mathrm{H}_{2}$ with a $\mathrm{Pt}$ sensing electrode, and in the measurement of dissolved $\mathrm{H}_{2} \mathrm{~S}$ with a $\mathrm{Ag} \mid \mathrm{Ag}_{2} \mathrm{~S}$ sensing electrode. The voltage potential between the electrodes in each cell is related
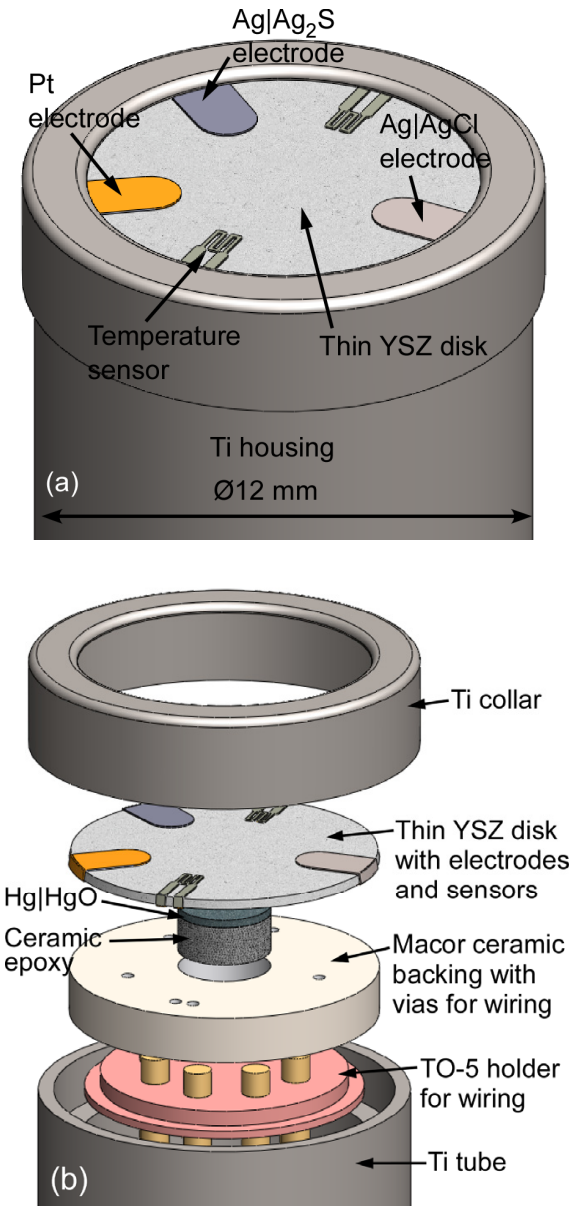

Figure 1: Schematics of the micromachined sensor proposed for analysis of geofluids in harsh environments. (a) Perspective view of the full device, showing sensing electrodes and temperature sensors (RTDs) on the thin YSZ disk and the $\Phi 12 \mathrm{~mm}$ titanium housing. (b) Exploded view showing individual components inside the Ti housing.

Solid-State Sensors, Actuators, and Microsystems Workshop Hilton Head Island, South Carolina, June 3-7, 2012 


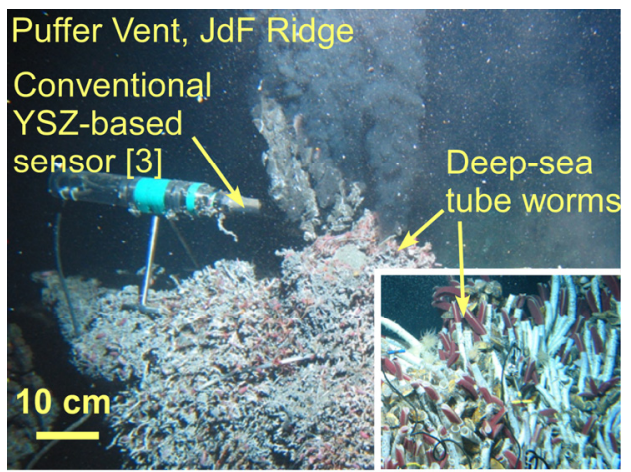

Figure 2: Exploration of deep sea hydro-thermal vents using manned submersible assets [3]. Photo shows deployment of a conventional YSZ-based sensor unit at Puffer Vent of Juan de Fuca Ridge.

Table I: Electrochemical cells and their corresponding electrodes in the micromachined chemical sensor.

\begin{tabular}{|l|l|}
\hline Sensing target & \multicolumn{1}{|c|}{ Electrochemical cell } \\
\hline $\mathrm{pH}$ & $\mathrm{Ag}|\mathrm{AgCl}|$ Target solution $|\mathrm{YSZ}| \mathrm{HgO} \mid \mathrm{Hg}$ \\
\hline Dissolved $\mathrm{H}_{2}$ & $\mathrm{Pt} \mid \mathrm{Target}$ solution $|\mathrm{YSZ}| \mathrm{HgO} \mid \mathrm{Hg}$ \\
\hline Dissolved $\mathrm{H}_{2} \mathrm{~S}$ & $\mathrm{Ag}\left|\mathrm{Ag}_{2} \mathrm{~S}\right|$ Target solution $|\mathrm{YSZ}| \mathrm{HgO} \mid \mathrm{Hg}$ \\
\hline
\end{tabular}

to the corresponding target chemical quantity by $[3,7]$ :

$$
\begin{aligned}
& V_{p H, T, P}=V_{p H}^{0}-\frac{2.303 R T}{F}\left(\log a_{\mathrm{Cl}^{-}}-\frac{1}{2} \log a_{\mathrm{H}_{2} \mathrm{O}}-\mathrm{pH}_{\mathrm{t}}\right) \\
& V_{\mathrm{H}_{2}, T, P}=V_{\mathrm{Hg} \mid \mathrm{HgO}}^{0}+\frac{2.303 R T}{2 F} \log \left(\frac{K_{H} \cdot \gamma_{\mathrm{H}_{2}} \cdot m_{\mathrm{H}_{2}}}{a_{\mathrm{H}_{2} \mathrm{O}}}\right) \\
& V_{\mathrm{H}_{2} S, T, P}=V_{\mathrm{H}_{2} \mathrm{~S}}^{0}+\frac{2.303 R T}{2 F} \log \left(\frac{K_{H} \cdot \gamma_{\mathrm{H}_{2} \mathrm{~S}} \cdot m_{\mathrm{H}_{2} \mathrm{~S}}}{a_{\mathrm{H}_{2} \mathrm{O}}}\right)
\end{aligned}
$$

where $V_{p H, T, P}, V_{H 2, T, P}, V_{H 2 S, T, P}$ are measured voltage potentials in corresponding cells, $V_{p H}^{0}$ and $V_{H 2 S}^{0}$ are the standard cell potentials at the appropriate temperatures and pressure and the values can be determined from the standard state potentials of $\mathrm{Ag}|\mathrm{AgCl}, \mathrm{Ag}| \mathrm{Ag}_{2} \mathrm{~S}$ and $\mathrm{Hg} \mid \mathrm{HgO}$ electrodes (i.e. $V_{A g \mid A g C l}^{0}, V_{A g \mid A g 2 S}^{0}$ and $V_{H g \mid H g O}^{0}$, respectively), $a$ is the activity of the chemical component, $R$ is the gas constant, $F$ is the Faraday constant, $T$ is temperature in $\mathrm{K}, p H_{t}$ is the $\mathrm{pH}$ to be measured, $K_{H}$ is the Henry's law constant, $\gamma_{H 2}$ and $\gamma_{H 2 S}$ are the activity coefficients of $\mathrm{H}_{2}$ and $\mathrm{H}_{2} \mathrm{~S}$, and $m_{H 2}$ and $m_{H 2 S}$ are the dissolved $\mathrm{H}_{2}$ and $\mathrm{H}_{2} \mathrm{~S}$ concentrations, respectively. With a DC measurement of the corresponding cell potential at the target temperature and pressure, direct sensing of each chemical quantity can be obtained. Temperature sensing is performed by two Pt-film resistance-temperature-detectors (RTD) through a measurement in resistance change of the Pt films.

The schematics of the sensor design are shown in Fig. 1 and Fig. 3. All sensor components are integrated at the end of a titanium tube. A thin YSZ disk/diaphragm is used for ion conduction to the underneath $\mathrm{Hg} \mid \mathrm{HgO}$ paste electrode. The thickness of the YSZ disk should be small enough $(<<1 \mathrm{~mm})$ to allow sufficient ion conduction for the sensing purpose at temperatures below $100^{\circ} \mathrm{C}$. The disk is also a common substrate for other thin metal-film electrodes $\left(\mathrm{Ag} \mid \mathrm{AgCl}, \mathrm{Pt}\right.$ and $\mathrm{Ag} \mid \mathrm{Ag}_{2} \mathrm{~S}$ ) and RTDs. Electrical connections from these electrodes/RTDs run over a $10^{\circ}$-tapered sidewall of the YSZ disk to the backside. No through-hole or cavity is present on the YSZ surface to avoid leakage under pressure. The YSZ disk is supported by a Macor ${ }^{\mathbb{B}}$ ceramic disk, which has feedthroughs for electrical connection

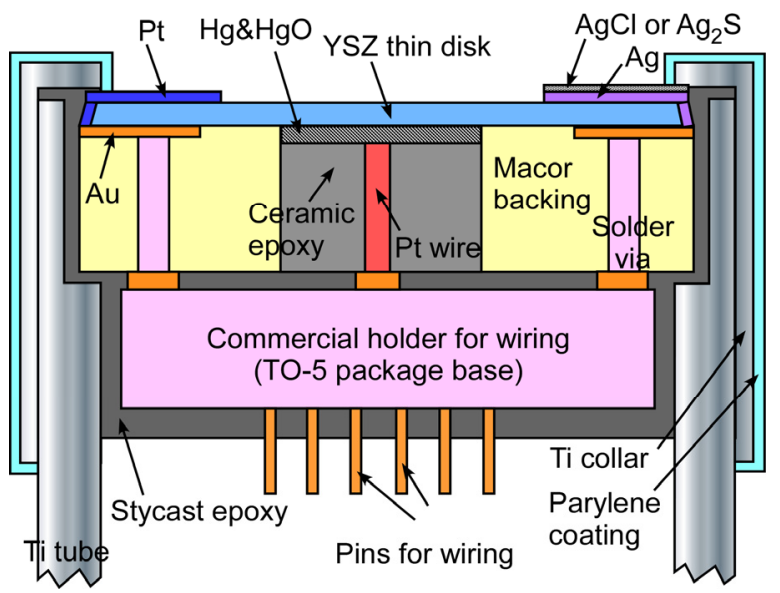

Figure 3: Schematic of the micromachined sensor in $2 D$ crosssectional view, showing integration of individual components. Note that parylene is selectively coated on the sensor external surface, covering RTDs but not other electrodes.

from the backside of the YSZ disk to a commercial TO-5 holder for cable wiring. The $\mathrm{Hg} \mid \mathrm{HgO}$ paste is sealed inside a cavity in the Macor disk by ceramic epoxy, with a Pt wire going out for electrical connection (Fig. 3). The Ti tube covers all sidewalls of internal components, and a Ti collar wraps around the edge of the YSZ front surface, minimizing potential leak path. High-strength vacuum-sealing Stycast epoxy encapsulates all internal components and seals the Ti housing. Selective coating of parylene or other polymers provides additional device sealing and electrical insulation for RTDs.

\section{DEVICE FABRICATION}

The YSZ disks were custom-made using Type ZDY-4 material (CoorsTek, Inc., CO, USA). In order to deposit thin-film metal electrodes/RTDs on the surface of the YSZ disk, a shadow mask was used. The metal films, including Pt and Ag on the front side and $\mathrm{Au}$ on the backside of the disk, were sequentially deposited by sputtering or evaporation through the corresponding patterns on the shadow mask. The thicknesses of the metal films are $200 / 1000 \AA$ for $\mathrm{Ti} / \mathrm{Pt}$, and $500 / 20000 \AA$ for $\mathrm{Ti} / \mathrm{Ag}$, and $500 / 5000 \AA$ for $\mathrm{Ti} / \mathrm{Au}$. Features were included on the shadow mask to allow alignment between different metal films. The thin-

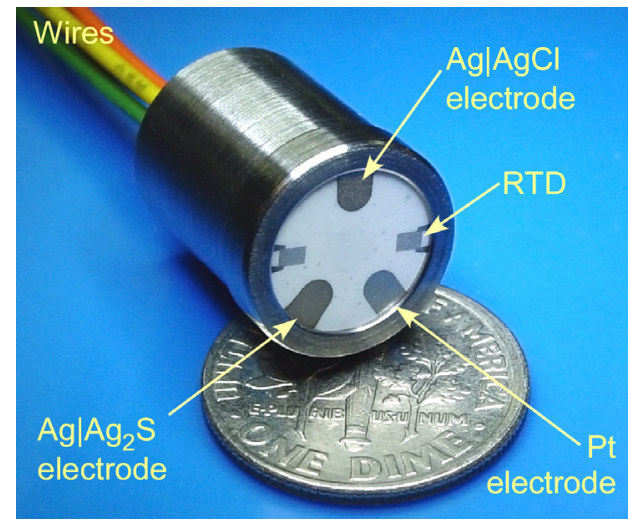

Figure 4: Photo of an integrated device on a US dime, showing $\mathrm{Ag}|\mathrm{AgCl}, \mathrm{Ag}| \mathrm{Ag}_{2} \mathrm{~S}$ and Pt electrodes and $30 \mu \mathrm{m}$-wide Pt lines for RTDs, before selective parylene coating. The $15 \mathrm{~mm}$ length of the Ti tube is for demonstration only. Effective sensor length from YSZ disk to TO-5 holder: $\approx 6 \mathrm{~mm}$. 


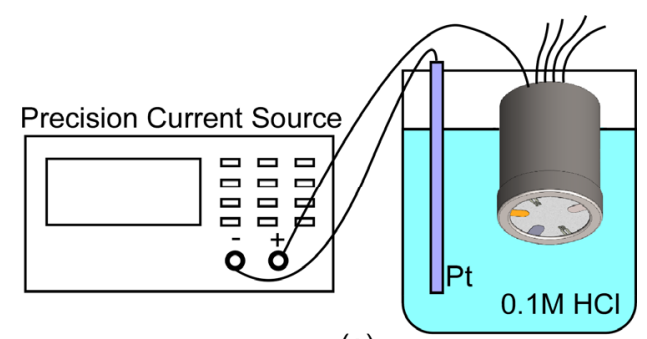

(a)

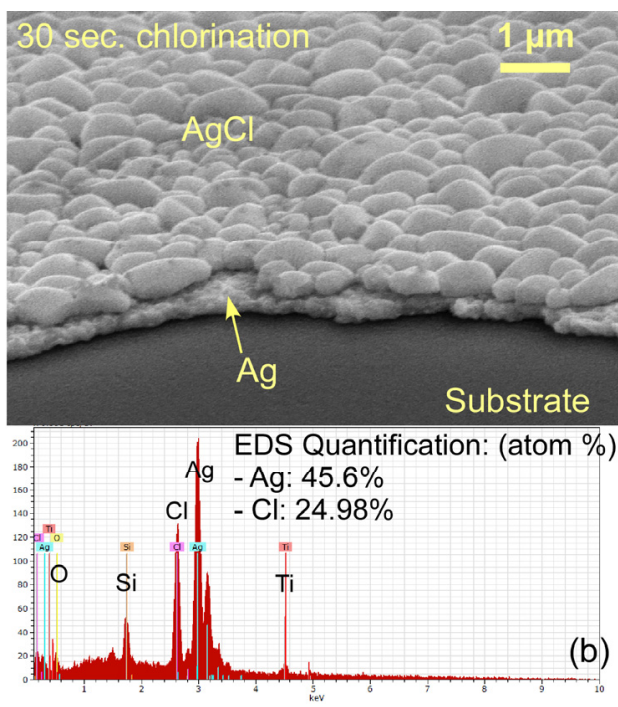

Figure 5: (a) Setup for silver chlorination. The counter electrode is a silicon wafer evaporation-coated with $5000 \AA$ platinum. Current density: $2 \mathrm{~mA} / \mathrm{cm}^{2}$. (b) SEM image and EDS analysis result of the chlorinated Ag film on a glass test substrate.

film RTDs consist of $30 \mu \mathrm{m}$-wide folded Pt lines and have a resistance of $\approx 200 \Omega$ each. The $10^{\circ}$-tapered edge of the YSZ disk allowed metal to be deposited on the slope to make the electrical connection to the backside of the disk.

The $\mathrm{Hg} \mid \mathrm{HgO}$ paste was formed by mixing $\mathrm{Hg}(99.9998 \%$ purity) and $\mathrm{HgO}$ (99.998\% purity) (Alfa Aesar, MA, USA). The Macor ceramic disk was custom-made by micromilling using material obtained from McMaster, NJ, USA. The disk has a thickness of $1.588 \mathrm{~mm}$. The center cavity on the disk for $\mathrm{Hg} \mid \mathrm{HgO}$ paste and ceramic epoxy has a diameter of $3 \mathrm{~mm}$. The electrical feedthroughs/vias have a diameter of $500 \mu \mathrm{m}$. The Ti tube and collar were custom-machined from Grade $5 \mathrm{Ti}$ alloy (Ti-6Al-4V, McMaster, NJ, USA), which has excellent mechanical strength and corrosion resistance. A photo of an integrated device is shown in Fig. 4. The effective length of the sensor from the YSZ disk to the TO-5 holder is $\approx 6 \mathrm{~mm}$.

After the sensor components were integrated, the $2 \mu \mathrm{m}$-thick Ag films on the YSZ disk were activated by chlorination and sulfurization, turning the $\mathrm{Ag}$ films into $\mathrm{Ag} \mid \mathrm{AgCl}$ and $\mathrm{Ag} \mid \mathrm{Ag}_{2} \mathrm{~S}$ electrodes, respectively. For silver chlorination, the sensor was dipped into an $\mathrm{HCl}$ solution with a concentration of $0.1 \mathrm{M}$ (Fig. 5a). The counter electrode was a silicon wafer with an evaporated $5000 \AA$-thick Pt film. The current density used for chlorination was $2 \mathrm{~mA} / \mathrm{cm}^{2}$. This current level has been reported to provide a uniform coating of $\mathrm{AgCl}$ with a grain size around $1 \mu \mathrm{m}$ [8]. For silver sulfurization, an electrochemical cell of $\mathrm{Ag}|\mathrm{AgCl}| \mathrm{S}^{2-}$ $\left|\mathrm{Ag}_{2} \mathrm{~S}\right| \mathrm{Ag}$ was formed. The electrodes in the cell were a separately-built $\mathrm{Ag} \mid \mathrm{AgCl}$ electrode and the target $\mathrm{Ag}$ film on the sensor; a $\mathrm{Na}_{2} \mathrm{~S}$ solution was used as the electrolyte. The $\mathrm{Ag} \mid \mathrm{AgCl}$ electrode that was formed on the sensor was protected by a photoresist coating. The target $\mathrm{Ag}$ film on the sensor was sulfurized by externally shorting the cell.

\section{EXPERIMENTAL RESULTS}

The chlorination procedure was characterized using a Ag film coated on a glass substrate. This Ag film was deposited by sputtering in the same session when the Ag films on the YSZ disks were deposited. The obtained $\mathrm{Ag} \mid \mathrm{AgCl}$ film is shown in the upper portion of Fig. 5(b). The $\mathrm{AgCl}$ layer has a grain size of $\approx 1 \mu \mathrm{m}$ as expected and is uniformly coated on the remaining Ag layer. Energy dispersive spectroscopy (EDS) was done to characterize the electrode and the obtained spectrum is shown in the lower portion of Fig. 5(b). According to the EDS quantification result, the electrode has $45.6 \%$ atom percentage for $\mathrm{Ag}$ and $24.98 \%$ for $\mathrm{Cl}$, suggesting a ratio of $\approx 1$ between $\mathrm{Ag}$ and $\mathrm{AgCl}$.

As a common electrode for all three chemical sensing functions, the $\mathrm{YSZ}|\mathrm{HgO}| \mathrm{Hg}$ solid electrode is the core component of the sensor. It also presented the most challenge in the fabrication of all four electrodes. $\mathrm{pH}$ measurements in a regular laboratory setting using this electrode can provide direct verification of its integrity and functionality. In these measurements, hydrochloric acid solutions with $\mathrm{pH}$ ranging in 25.5 were used. The $\mathrm{pH}$ values were verified with a double-junction pH meter (Oakton ${ }^{\circledR}$ pHTestr $3+$ ), which has an accuracy of 0.1 . Before it was used, the meter was calibrated with certified $\mathrm{pH}$ buffer solutions from Fisher Scientific. The $\mathrm{HCl}$ solutions were heated on a hotplate to $35^{\circ} \mathrm{C}$, and a thermocouple was used to monitor the solution temperature. The voltage potential between the $\mathrm{Ag} \mid \mathrm{AgCl}$ and $\mathrm{YSZ}|\mathrm{HgO}| \mathrm{Hg}$ electrodes on the sensor was read out by an Agilent 34401A multimeter with its input resistance set at $>10 \mathrm{G} \Omega$.

As shown in Fig. 6, the plot of measured $V_{p H, T, P}$ vs. pH has a slope of $123.2 \mathrm{mV} / \mathrm{pH}$. This slope is about double the Nernst slope of $61.14 \mathrm{mV} / \mathrm{pH}$ at $35^{\circ} \mathrm{C}$. This is due to the presence of both $\mathrm{H}^{+}$ and $\mathrm{Cl}^{-}$ions in the solutions. The $\mathrm{YSZ}|\mathrm{HgO}| \mathrm{Hg}$ electrode is sensitive to $\mathrm{H}^{+}$ions while the $\mathrm{Ag} \mid \mathrm{AgCl}$ electrode is sensitive to $\mathrm{Cl}^{-}$ ions. In a regular laboratory environment, the strong $\mathrm{HCl}$ acid can generate equal concentrations of $\mathrm{H}^{+}$and $\mathrm{Cl}^{-}$in the solution

$$
\log a_{\mathrm{Cl}^{-}}=\log a_{\mathrm{H}^{+}}=-\mathrm{pH}_{\mathrm{t}}
$$

Assume the activity of $\mathrm{H}_{2} \mathrm{O}$ in the regular lab environment is 1 ,

$$
\log a_{\mathrm{H}_{2} \mathrm{O}}=0
$$

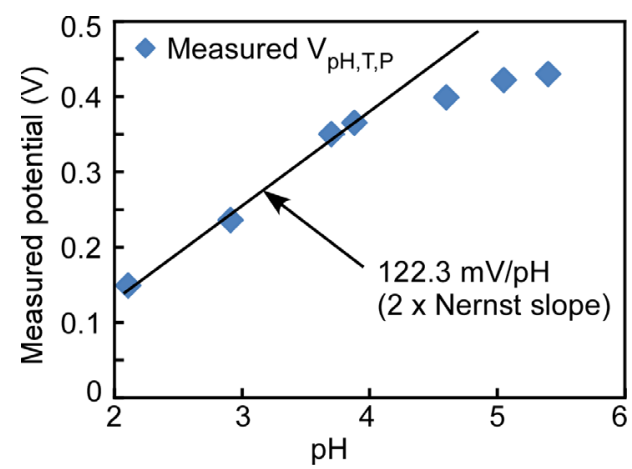

Figure 6: Measured potential between the $\mathrm{Ag} \mid \mathrm{AgCl}$ and $Y \mathrm{SZ}|\mathrm{HgO}| \mathrm{Hg}$ electrodes, vs. $\mathrm{pH}$ of $\mathrm{HCl}$ solutions at $35^{\circ} \mathrm{C}$. The straight line plots double the Nernst slope of $61.14 \mathrm{mV} / \mathrm{pH}$ at $35^{\circ} \mathrm{C}$ for comparison. This slope is due to the effect of both $\mathrm{H}^{+}$and $\mathrm{Cl}^{-}$. For $\mathrm{pH}>4, V_{p H, T, P}$ saturates. This may be due to activity of $\mathrm{H}^{+}$and $\mathrm{OH}^{-}$from $\mathrm{H}_{2} \mathrm{O}$ at higher $\mathrm{pH}$, and also of low $\mathrm{Cl}^{-}$for $\mathrm{Ag} \mid \mathrm{AgCl}$ electrode. 
Sensor Test with 2-12 $\mathrm{mMol} / \mathrm{kg} \mathrm{H}_{2} \mathrm{~S}$ in Water

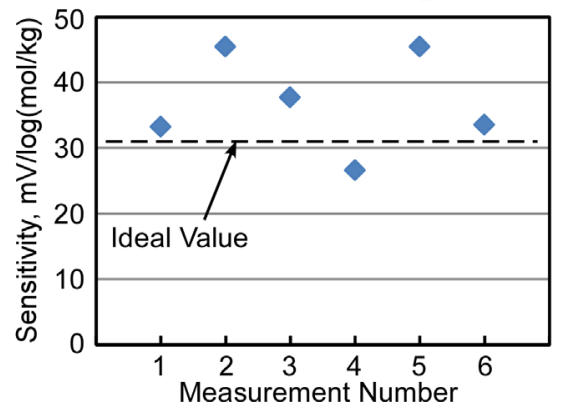

Figure 7: Sensitivity of measured sensor responses to the $\mathrm{H}_{2} \mathrm{~S}$ concentration in water, and comparison to the ideal value of 30.6 $\mathrm{mV} / \log (\mathrm{mol} / \mathrm{kg})$. The sensor output potential was taken between the $\mathrm{YSZ}|\mathrm{HgO}| \mathrm{Hg}$ and $\mathrm{Ag} \mid \mathrm{Ag}_{2} \mathrm{~S}$ electrodes at $35^{\circ} \mathrm{C}$. Differences from the ideal value are related to uncertainty in the $\mathrm{H}_{2} \mathrm{~S}$ concentration.

Equation (1), which provides the relationship between the measurement voltage potential and $\mathrm{pH}$, can be simplified as

$$
V_{p H, T, P}=V_{p H}^{0}+2 \cdot \frac{2.303 R T}{F} \mathrm{pH}_{\mathrm{t}}
$$

This indicates that the expected slope of $V_{p H, T, P}$ vs. $\mathrm{pH}$ is double the Nernst slope. At $35^{\circ} \mathrm{C}$, the expected slope is $122.3 \mathrm{mV} / \mathrm{pH}$, and the measured value is comparable to it. This indicates the validity of the $\mathrm{pH}$ sensor design and the integrity of the YSZ $|\mathrm{HgO}| \mathrm{Hg}$ core electrode.

Also shown in Fig. 6, $V_{p H, T, P}$ saturates at $\mathrm{pH}$ values $>4$. This may be due to activity of $\mathrm{H}^{+}$and $\mathrm{OH}^{-}$from $\mathrm{H}_{2} \mathrm{O}$ at higher $\mathrm{pH}$, and also low $\mathrm{Cl}^{-}$activity at low $\mathrm{HCl}$ concentration for the $\mathrm{Ag} \mid \mathrm{AgCl}$ electrode.

$\mathrm{H}_{2} \mathrm{~S}$ sensing was tested using hydrogen sulfide water (Grainger, Inc., USA) with varying concentration estimated in the range of $2-12 \mathrm{mMol} / \mathrm{kg}$. The sensor output potential was taken between the $\mathrm{YSZ}|\mathrm{HgO}| \mathrm{Hg}$ and $\mathrm{Ag} \mid \mathrm{Ag}_{2} \mathrm{~S}$ electrodes at $35^{\circ} \mathrm{C}$. The sensitivity of the sensor - i.e. the change in output potential per unit change in the $\mathrm{H}_{2} \mathrm{~S}$ concentration - was typically 26-45 $\mathrm{mV} / \log (\mathrm{mol} / \mathrm{kg})$ (Fig.7). The ideal value is $30.6 \mathrm{mV} / \log (\mathrm{mol} / \mathrm{kg})$ according to Equation 3. Differences from the ideal value are related to uncertainty in the $\mathrm{H}_{2} \mathrm{~S}$ concentration, which can vary from the estimated value due to reasons such as oxidation of dissolved sulfide into sulfate.

\section{DISCUSSION}

As described in the experimental results, the sensor responds to both $\mathrm{H}^{+}$and $\mathrm{Cl}^{-}$concentrations in the $\mathrm{pH}$ measurement without a buffer solution that provides a constant $\mathrm{Cl}^{-}$concentration for the $\mathrm{Ag} \mid \mathrm{AgCl}$ electrode. This makes it difficult to use the sensor in regular applications, though approaches such as a coating of $\mathrm{KCl}$ gel on the $\mathrm{Ag} \mid \mathrm{AgCl}$ electrode can provide simple solutions [8]. However, in the target environments at hydrothermal vents, the sea water presents a saturated $\mathrm{Cl}^{-}$concentration that is mostly constant, rendering these additional techniques unnecessary.

The sensor has been tested for $\mathrm{pH}$ and $\mathrm{H}_{2} \mathrm{~S}$ measurement in a laboratory environment. Although the sensor is designed for high pressure and relatively high temperature applications, its performance in harsh environments remains to be evaluated. This, together with the sensing function for dissolved $\mathrm{H}_{2}$ and temperature, will be verified in future efforts.

\section{CONCLUSIONS}

A micromachined chemical sensor intended for applications in harsh environments has been design and implemented. Sensing functions for $\mathrm{pH}$, dissolved $\mathrm{H}_{2}$ and $\mathrm{H}_{2} \mathrm{~S}$, and temperature are included. Techniques for silver chlorination and sulfurization have been developed and characterized to activate the $\mathrm{Ag} \mid \mathrm{AgCl}$ reference electrode for $\mathrm{pH}$ sensing and the $\mathrm{Ag} \mid \mathrm{Ag}_{2} \mathrm{~S}$ sensing electrode for $\mathrm{H}_{2} \mathrm{~S}$ sensing. Initial measurement results for $\mathrm{pH}$ and $\mathrm{H}_{2} \mathrm{~S}$ sensing in a regular laboratory environment indicate validity of the sensor design and the integrity of the $\mathrm{YSZ}|\mathrm{HgO}| \mathrm{Hg}$ core component. Further characterization of sensor functions as well as device testing under harsh environments will be pursued in future effort.

\section{ACKNOWLEDGEMENT}

The research effort was supported in part by the National Science Foundation. Facilities used for this research include the Lurie Nanofabrication Facility (LNF) operated by the Solid-State Electronics Laboratory (SSEL) at the University of Michigan.

\section{REFERENCES}

[1] S. Begley, "Mining's Final Frontier", Newsweek, pp. 50-52, Sep. 20, 2010

[2] K. Ding and W.E. Seyfried, Jr., "Direct $\mathrm{pH}$ measurement of $\mathrm{NaCl}$-bearing fluid with an in situ sensor at $400^{\circ} \mathrm{C}$ and 40 megapascals," Science, 272, pp. 1634-1636, 1996

[3] K. Ding and W.E. Seyfried, Jr., "In situ measurement of $\mathrm{pH}$ and dissolved $\mathrm{H} 2$ in mid-ocean ridge hydrothermal fluids at elevated temperatures and pressures," Chem. Rev., 107, pp. 601-622, 2007

[4] Y. Pan and W.E. Seyfried, Jr., "Experimental and theoretical constraints on $\mathrm{pH}$ measurements with an Iridium oxide electrode in aqueous fluids from 25 to $175^{\circ} \mathrm{C}$ and $25 \mathrm{MPa}$.," J. Solution Chem., 37, pp. 1051-1062, 2008

[5] L.W. Niedrach, "A new membrane-type $\mathrm{pH}$ sensor for use in high temperature-high pressure water," J. Electrochem. Soc., 127 , pp. 2122-30, 1980

[6] D.D. Macdonald, S. Hettiarachchi, and S.J. Lenhart, "The thermodynamic viability of yttria-stabilized zirconia $\mathrm{pH}$ sensors for high temperature aqueous solutions," J. Solution Chem., 17(8), pp. 719-732, 1988

[7] K. Ding, W.E. Seyfried, Jr., M.K. Tivey, and A.M. Bradley, "In situ measurement of dissolved $\mathrm{H}_{2}$ and $\mathrm{H}_{2} \mathrm{~S}$ in hightemperature hydrothermal vent fluids at the Main Endeavour Field, Juan de Fuca Ridge," Earth and Planetary Science Letters, 186(3-4), pp. 417-25, Apr. 2001

[8] I-Y. Huang, R.-S. Huang, and L.-H. Lo, "Improvement of integrated $\mathrm{Ag} / \mathrm{AgCl}$ thin-film electrodes by $\mathrm{KCl}$-gel coating for ISFET applications," Sensors and Actuators B: Chemical, 94(1), pp. 53-64, 2003

\section{CONTACT}

*Tao Li, 1301 Beal Ave., Ann Arbor, MI, 48109, USA; tel: 1-734615-7983; fax: 1-734-763-9324; email: litz@umich.edu 